\title{
Konstruksi Skala Kepedulian terhadap Penggunaan Energi
}

\author{
Rizal Kurniawan, Saifuddin Azwar \\ Program Magister Psikologi Fakultas Psikologi Universitas Gadjah Mada \\ rizal.kurniawan@mail.ugm.ac.id
}

\begin{abstract}
Using electricity and fuel oil might have some negative impact towards the national economy and the environment. Psychological scale for measuring awareness of energy usage has never been tested before. The main purpose of this study is to construct psychological scale for measuring energy usage. The concept of Amburgey (2012) has been used to describe of psychological concern that are perceived threat and desired change. Perceived threat is an evaluation of a person to a problem and desired change is one's willingness to resolve that problem. Four hundred-thirty eight students were enrolled in this study with a mean of age 21 years old. The results of content item validation show that one item from perceived threat's subscale has value of Aiken (V) less than .50 and all of items from desired change's subscale have $V$ value greater than .50. Result from item's discrimination process show that $40 \%$ items from perceived threat's subscale has low of discrimination power and desired change's sub scale has $31 \%$. Alpha value for perceived threat's subscales is .76 and desired change's sub scale is .78. The concern for energy usage scale has poor model fit.
\end{abstract}

Key words: energy usage, psychometrics, perceived threat, desired change

\begin{abstract}
Abstrak. Penggunaan listrik dan bahan bakar minyak (BBM) dapat berakibat buruk bagi anggaran belanja negara dan lingkungan. Sejauh ini belum ada alat ukur untuk kepedulian terhadap penggunaan energi. Tujuan dari penelitian ini adalah untuk membuat alat ukur kepedulian individu terhadap penggunaan energi. Konsep Amburgrey (2012) digunakan untuk menjelaskan tentang peduli yaitu evaluasi seseorang terhadap permasalahan yang terjadi (perceived threat) dan keinginan seseorang untuk bertindak dalam menyelesaikan permasalahan tersebut (desired change). Sebanyak 438 orang mahasiswa menjadi responden pada penelitian ini dengan rerata umur 21 tahun. Hasil validasi isi aitem menunjukkan terdapat satu aitem dari sub skala perceived threat yang memiliki nilai Aiken (V) yang kurang dari .50, sedangkan semua aitem pada sub skala desired change memiliki nilai $\mathrm{V}$ besar dari .50. Hasil perhitungan daya beda aitem menunjukkan sebanyak $40 \%$ aitem dari sub skala perceived threat memiliki daya beda kurang dari .25 sedangkan sub skala desired change sebanyak $31 \%$. Reliabilitas sub skala perceived threat adalah sebesar .76 sedangkan sub skala desired change sebesar .78. Skala kepedulian terhadap penggunaan energi memiliki struktur internal yang belum memadai.
\end{abstract}

Kata kunci : penggunaan energi, psikometri, perceived threat, desired change

Jumlah penduduk Indonesia terus mengalami peningkatan dari tahun ke tahun. Data Badan Pengembangan Statistik (2013) menunjukkan bahwa peningkatan tersebut mencapai angka dua juta per tahun. Pertumbuhan jumlah penduduk tersebut tentu akan diikuti oleh peningkatan kebutuhan yang harus mereka penuhi, mulai dari kebutuhan makanan, tempat tinggal, kesehatan dan sebagainya (Osumanu, 2007). Salah satu kebutuhan penting lainnya adalah kebutuhan akan energi, yang berfungsi untuk mempermudah kegiatan mereka sehari-hari. 
Sejauh ini penggunaan sumber energi di Indonesia masih berfokus kepada sumber energi yang tidak terbaharui, seperti minyak bumi, gas, dan batubara. Hal itu dapat dilihat dari konsumsi minyak bumi dan batu bara yang terus meningkat dari tahun 1990 sampai 2010. Sementara itu penggunaan energi terbaharui jumlahnya hanya sedikit dan tidak mengalami peningkatan pemakaian pada interval tahun tersebut (Kementrian Energi dan Sumber Daya Mineral, 2011).

Penggunaan energi yang hanya terfokus pada minyak bumi dan batu bara dapat menyebabkan terjadinya penipisan sumber energi di Indonesia. Wijaya (2010) menyatakan bahwa bila tidak ada sumber energi baru ditemukan atau tidak adanya pengembangan sumber energi yang terbarukan dilakukan, maka sepuluh sampai lima belas tahun ke depan sumber energi di Indonesia akan habis. Bila kejadian itu terjadi maka Indonesia akan mengimpor sumber energi dari negara lain yang tentunya akan memberatkan anggaran negara.

Semua pihak memiliki kepentingan terhadap ketersediaan energi tersebut. Sektorsektor yang paling banyak menggunakan sumber energi secara berturut-turut adalah industri, transportasi, rumah tangga dan komersial (Kementrian Energi dan Sumber Daya Mineral, 2011). Terkait dengan hal itu, mahasiswa juga memiliki peran dengan penggunaan energi tersebut. Selain digunakan untuk kebutuhan mereka di rumah atau di kos, energi juga mereka perlukan untuk kebutuhan transportasi. Survey yang dilakukan oleh Singhirunnusorn, Luesopa, Pansee, dan Sahachaisaeree (2012) menyatakan bahwa untuk sampai ke kampus, sebanyak 68\% dari 250 mahasiswa lebih suka menggunakan kendaraan bermotor, 23\% menggunakan angkutan umum dan hanya $9 \%$ mahasiswa yang berjalan kaki. Mereka juga cenderung mempunyai perhatian yang rendah terhadap penggunaan energi (Yen, 2010). Berdasarkan permasalahan tersebut, peneliti merasa penting untuk mengetahui tentang bagaimana gambaran tingkat kepedulian mahasiswa terhadap penggunaan energi.

Untuk mengetahui tingkat kepedulian seseorang terhadap penggunaan energi tentu harus melalui proses pengukuran psikologis secara objektif. Pengukuran kepedulian merupakan pengukuran variabel laten yang merupakan kajian psikometri, sehingga proses pengukuran harus dilakukan dengan menggunakan alat ukur psikologis yang valid dan reliabel (Furr \& Bacharach, 2009). Tujuan utama dari penelitian ini adalah mengkonstruksikan alat ukur psikologis untuk mengukur tingkat kepedulian seseorang terhadap penggunaan energi.

\section{Konsep kepedulian}

Pendekatan awal, kepedulian disamakan dengan sikap (Hasla, Gamble, Juliusson, \& Garling, 2008). Sikap merupakan hasil evaluasi seseorang terhadap sesuatu. Orang yang peduli menurut pendekatan ini adalah mereka yang mempunyai sikap yang positif terhadap sesuatu. Sikap tidak dapat berdiri sendiri melainkan harus memiliki objek. Sehingga, kepedulian juga harus memiliki objek. Misalnya, untuk menyatakan seseorang peduli terlebih dahulu harus diketahui objek pedulinya terhadap apa, korban bencana, kerusakan lingkungan, atau objek lainnya. Beberapa ahli lain juga menyatakan bahwa kepedulian merupakan fungsi dari sikap (misal, Dunlap, Van Liere, Mertig, \& Jones, 2000; Dunlap, 2008; Karpiak \& Baril 2008; Urban \& Scasny, 2012).

Pendekatan ke dua dari konsep kepedulian adalah value. Pendekatan ini menggunakan teori value belief norm (VBN) dari Stern (1992). Menurut pendekatan ini, rasa peduli terbentuk berdasarkan value apa yang dirasa penting ketika seseorang berhadapan dengan sesuatu yang menjadi objek kepedulian yang ia rasakan. Teori VBN menyatakan ada tiga jenis value, yaitu 
egoistik yaitu seseorang yang mengutamakan diri sendiri ketika kepedulian muncul. Misalnya seseorang yang peduli terhadap kebersihan lingkungan dengan tujuan menghindari sumber penyakit yang bisa berdampak buruk pada dirinya. Altruistik yaitu kepedulian yang mengutamakan orang lain. Misalnya seseorang yang menjaga kebersihan lingkungan dengan tujuan supaya orang lain merasa nyaman ketika lewat di perkarangan rumahnya. Biosferik yaitu kepedulian yang mengutamakan makhluk hidup lain. Misalnya seseorang yang menjaga kebersihan lingkungan dengan tujuan untuk menjaga kesuburan tanah (Karpiak \& Baril, 2008, Snelgar, 2006).

Keterbatasan pendekatan sikap dan value adalah keduanya bersifat pasif atau sesorang hanya bisa merasakan permasalahan yang terjadi saja. Pendekatan sikap dan value belum bisa menjelaskan bagaimana seseorang
Amburgrey (2012) menambahkan motivasi ke dalam konsep kepedulian untuk merevisi konsep sebelumnya. Ia menyatakan bahwa seseorang yang sedang peduli itu tidak hanya meliputi bagaimana ia merasakan permasalahan yang terjadi saja, namun juga bagaimana ia termotivasi untuk ikut terlibat di dalam menyelesaikan permasalahan tersebut.

Pendekatan yang kembangkan oleh Amburgrey (2012) menyatakan bahwa kepedulian lingkungan ditentukan oleh besarnya ancaman kerusakan lingkungan yang dirasakan oleh seseorang (perceived threat) dan besarnya keinginan ia untuk menyelesaikan permasalahan yang tersebut (desired change). Semakin tinggi tingkat kedua variabel pada diri seseorang maka dapat dikatakan orang tersebut peduli terhadap sesuatu yang terjadi. Dalam konstruksinya konsep yang dikembangkan oleh Amburgrey

Tabel 1. Dimensi, Aspek dan Operasional Konsep Kepedulian Lingkungan.

\begin{tabular}{cll}
\hline Dimensi & Aspek & \multicolumn{1}{c}{ Operasional } \\
\hline Perceived threat & Harm & $\begin{array}{l}\text { Sejauh mana seseorang merasa permasalahan sebagai suatu yang } \\
\text { mengancam. } \\
\text { Sejauh mana seseorang merasa permasalahan yang terjadi sebagai } \\
\text { suatu yang bahaya } \\
\text { Sejauh mana seseorang merasa takut dengan permasalahan yang } \\
\text { terjadi }\end{array}$ \\
Wesired change & Importance & $\begin{array}{l}\text { Sejauh mana seseorang merasa permasalahan yang terjadi } \\
\text { dirasakan penting untuk diperhatikan } \\
\text { Sejauh mana seseorang merasa penting untuk mengubah sesuatu } \\
\text { untuk menyelesaikan permasalahan yang terjadi } \\
\text { Sejauh mana seseorang merasa termotivasi untuk bertindak } \\
\text { terhadap permasalahan yang terjadi }\end{array}$ \\
& Motivation &
\end{tabular}

bisa aktif dalam menyikapi permasalahan yang terjadi. Selain itu, konsep VBN lebih menjelaskan jenis kepedulian dari pada tingkatannya. Artinya VBN akan menghasilkan variabel yang berbentuk kategorikal, tidak sejalan dengan tujuan dari penelitian ini yang berfokus kepada tingkatan kepedulian.

Salah satu variabel yang dapat digunakan untuk mengambarkan aktifnya seseorang dalam menyikapi suatu permasalahan yang terjadi adalah motivasi.
(2012) terdiri dari dua dimensi, yaitu perceived threat dan desired change. Masing-masing dimensi terdiri dari tiga aspek. Aspek untuk dimensi Perceived threat terdiri dari harm, danger, dan worry, sedangkan aspek dari dimensi desired change terdiri dari importance, upset dan motivation. Lebih lengkap gambaran bagaimana operasional konsep kepedulian lingkungan dari Amburgrey (2012) dapat dilihat pada Tabel 1.

$$
\text { Amburgrey (2012) dalam }
$$

mengembangkan telah 
menggunakan beberapa objek dari kepedulian seperti polusi udara, perubahan cuaca (climate change) dan kepunahan keanekaragaman hayati akibat dari perubahan iklim dunia (loss biodiversity). Sejauh ini, penggunaan konsep kepedulian yang dikembangkan Amburgrey (2012) oleh peneliti lain belum ditemukan. Penelitian ini akan mengunakan konsep amburgrey (2012) untuk melihat kepedulian terhadap penghematan energi.

\section{Metode}

Pendekatan yang digunakan untuk merancang skala pada penelitian ini adalah teori tes klasik. Menurut teori tes klasik, hasil yang di dapatkan dari proses pengukuran $\left(\mathrm{X}_{\mathrm{O}}\right)$ merupakan hasil dari skor murni $\left(\mathrm{X}_{\mathrm{T}}\right)$ dan erorr $\left(\mathrm{X}_{\mathrm{E}}\right)$. Semakin kecil nilai error yang didapatkan semakin baik pula hasil tes yang diperoleh. Teori tes klasik membedakan antara suatu aitem dengan aitem yang lain berdasarkan daya beda (Azwar, 2012; Furr dan Bacharach, 2009). Beberapa langkah yang dilakukan untuk menyusun skala pada penelitian ini adalah:

Menentukan indikator. Penentuan indikator dilakukan dengan cara melakukan diskusi dengan ahli. Dua orang ahli yang berpartisipasi dalam penelitian ini adalah dosen Fakultas Teknik Lingkungan UGM dan kepala Pusat Kajian Energi UGM.

Penulisan aitem. Aitem ditulis berdasarkan indikator yang telah ditentukan. Respon aitem menggunakan skala Likert yang terdiri dari "Sangat Setuju”, "Setuju”, "Antara Setuju dan Tidak Setuju", "tidak setuju" dan "Sangat Tidak Setuju". Aitem juga dibuat dalam bentuk favorable dan unfavorable. Aitem favorable akan diberi angka 5 bila respon sangat setuju dan angka 1 pada respon sangat tidak setuju dan sebaliknya.

Evaluasi kualitatif. Evaluasi kualitatif bertujuan untuk mengetahui keterbacaan aitem oleh responden, apakah responden dapat memahami aitem yang telah dibuat atau belum. Tujuh orang mahasiswa dilibatkan untuk berpartisipasi dalam proses ini. Mereka diberikan aitem-aitem yang telah selesai dirancang. Setelah itu mereka diberi waktu untuk merespon aitem-aitem dan memberikan komentar tentang aitem-aitem yang mereka anggap memiliki masalah seperti tata tulis dan kata yang tidak tepat. Komentar dari responden menjadi masukan penting untuk merevisi aitem lebih lanjut.

Validitas isi. Proses ini dilakukan untuk melihat kesesuian antara indikator dan aitem. Validitas isi ditentukan berdasarkan hasil dari jawaban rater. Proses ini dilakukan dengan cara memberikan lembaran penilaian kepada rater. Tugas rater adalah menilai tingkat kesesuaian aitem dengan indikatornya. Bila aitem dirasa sangat cocok dengan indikator maka diberi nilai 5 dan sebaliknya bila aitem dirasakan sangat tidak cocok dengan indikator maka diberi nilai 1 . Tiga puluh tiga orang yang terdiri dari dosen dan mahasiswa S2 telah berpartisipasi untuk menjadi rater. Hasil dari penilaian mereka dihitung dengan menggunakan persamaan Aiken (V) seperti pada rumus 1 yang sekaligus menjadi indeks validitas isi.

$\mathrm{V}=\frac{\sum(r-l o)}{n(c-1)}$

Dari persamaan 1, $\mathrm{r}$ adalah angka yang diberikan oleh penilai; lo adalah nilai validitas terendah (pada penelitian ini adalah 1); c adalah nilai validitas tertinggi (pada penelitian ini adalah 5); dan $\mathrm{n}$ adalah banyaknya rater yang berpartisipasi. Nilai $\mathrm{V}$ akan berkisar antara 0 sampai 1 . Semakin tinggi nilai $\mathrm{V}$ semakin cocok suatu aitem dengan indikatornya dan sebaliknya (Azwar, 2012). Nilai V yang digunakan pada penelitian ini adalah .50. Aitem yang memiliki nilai $\mathrm{V}$ di bawah .50 dianggap memiliki validitas isi yang lemah.

Daya beda aitem dan koefisien reliabilitas. Daya beda aitem merupakan ukuran suatu aitem untuk memisahkan responden yang 
memiliki atribut ukur yang tinggi dan yang rendah. Daya beda aitem dapat dilihat dari korelasi nilai suatu aitem dengan nilai total keseluruhan aitem $\left(\mathrm{r}_{\mathrm{i}-\mathrm{t}}\right)$. Semakin tinggi nilai $\mathrm{r}_{\mathrm{it}}$ semakin baik pula daya beda aitem tersebut dan sebaliknya. Nilai standar daya beda aitem yang digunakan pada penelitian ini adalah $\mathrm{r}_{\mathrm{i}-\mathrm{t}}$ $\geq$.20. Aitem yang memiliki nilai $r_{i-t}$ di bawah .20 dianggap memiliki daya beda yang rendah. Reliabilitas merupakan suatu ukuran tingkat kekonsistenan suatu skala. Skala yang memiliki reliabilitas yang tinggi akan cenderung menghasilkan skor yang cenderung sama ketika dilakukan pada waktu
.90), Root Mean Square error Approximation (RMSEA, fit bila $\leq .08)$ dan chi-square. Chi squrare dianggap fit bila memiliki nilai kecil dan tidak signifikan, namun bila jumlah responden besar nilai chi-square cenderung menjadi singnifikan (Kline, 2005).

Responden. Sebanyak 438 orang mahasiswa ikut berpartisipasi pada penelitian (171 (39\%) laki-laki). Rata-rata umur responden laki-laki dan perempuan adalah 20.8 dan 20.3. Perempuan memiliki skor perceived threat dan desired change lebih tinggi dibandingkan dengan laki-laki. Deskripsi subjek penelitian dapat dilihat pada Tabel 2.

Tabel 2. Deskripsi Responden Penelitian

\begin{tabular}{lcccccc}
\hline Gender & $\mathrm{N}$ & Umur & $\begin{array}{c}\text { Mean perceived } \\
\text { threat }(\mathrm{sd})\end{array}$ & Nilai t & $\begin{array}{c}\text { Mean desired } \\
\text { change }(\mathrm{sd})\end{array}$ & Nilai t \\
\hline Laki-laki & 171 & 20.8 & $\begin{array}{c}106.73(9.7) \\
109.58(10.2)\end{array}$ & $-2.95^{* *}$ & $101.37(10.7)$ & $-2.50^{*}$ \\
Perempuan & 267 & 20.3 & $104.01(10.9)$ & \\
\hline
\end{tabular}

Catatan: $\mathrm{sd}=$ standar deviasi; ${ }^{*}$ = signifikan pada taraf $.05{ }^{* *}=$ signifikan pada taraf .01.

yang berbeda (Azwar, 2012; Furr \& Bacharach, 2009). Reliabilitas pada penelitian ini dilihat dengan menggunakan alpha Cronbach.

Validitas. Validitas skala akan diuji dengan melihat struktur internal, apakah struktur skala yang dirancang cocok atau tidak dengan teori yang digunakan. Pemeriksaan struktur internal dilakukan dengan melakukan confirmatory factor analysis (CFA). Pengujian struktur dari sebuah model akan mengacu kepada model fit. Kriteria model fit yang akan digunakan pada penelitian ini adalah TukerLewis Indeks (TLI, fit bila nilainya $\geq .90$ ), Comparative Fit Index (CFI, fit bila nilainya $\geq$

\section{Hasil}

Validitas isi

Hasil perhitungan dengan menggunakan persamaan Aiken (V) didapatkan bahwa satu aitem gugur pada sub skala perceived threat yang mempunyai nilai $\mathrm{V}$ $=.47(\mathrm{~V}<.50)$, yaitu aitem yang berada pada aspek danger nomor 5. Aitem yang mempunyai nilai $\mathrm{V}$ paling tinggi pada sub skala perceived threat adalah aitem yang berada pada aspek worry nomor 9 dengan nilai V sebesar .82.

Nilai V untuk sub skala desired change berada pada interval .55 sampai .81. Hasil ini mengindikasikan bahwa tidak ada aitem

Tabel 3. Statistik Deskriptif

\begin{tabular}{lcccccc}
\hline Faktor/aspek & $\mathrm{k}$ & Skor hipotetik & Mean & Sd & Median & Skor empirik \\
\hline Perceived Threat & 30 & $30-150$ & 108.5 & 10.1 & 108 & $76-136$ \\
Harm & 10 & $10-50$ & 34.4 & 4.3 & 34 & $22-47$ \\
Danger & 11 & $11-55$ & 40.5 & 4.8 & 40.5 & $27-53$ \\
Worry & 9 & $9-45$ & 33.5 & 3.9 & 34 & $21-44$ \\
\hline Desired change & 29 & $29-145$ & 102.9 & 10.9 & 103 & $70-141$ \\
Importance & 10 & $10-50$ & 36.5 & 4.6 & 36.5 & $20-48$ \\
Upset & 10 & $10-50$ & 36.7 & 4.6 & 36 & $21-49$ \\
Motivation & 9 & $9-45$ & 30.2 & 4.5 & 30 & $14-45$ \\
\hline
\end{tabular}

Catatan: $\mathrm{sd}=$ standar deviasi; $\mathrm{k}=$ jumlah aitem. 
yang dibuang karena semua nilai $\mathrm{V}$ untuk setiap aitem besar dari .50. Nilai $\mathrm{V}$ terendah adalah aitem pada aspek importance nomor 5 dengan nilai V sebesar .55. Sedangkan untuk aitem yang mempunyai nilai $\mathrm{V}$ tertinggi adalah aitem pada aspek motivation nomor 9 dengan nilai $\mathrm{V}$ sebesar .81. Untuk lebih lengkapnya aitem dan nilai $\mathrm{V}$ untuk dua sub skala dapat dilihat pada Tabel 4.
Statistik deskriptif

Deskripsi statistik untuk skala kepedulian terhadap penggunaan energi dapat dilihat pada Tabel 3. Sub skala perceived threat memiliki 30 aitem yang terdiri dari 10, 11 dan 9 dari aspek harm, danger, worry secara berurutan. Sedangkan sub skala desired change teridiri dari 29 aitem yang berasal dari 10, 10 dan 9 aitem untuk aspek importance, upset dan motivation secara berurutan. Jarak nilai

Tabel 4. Validitas Isi dan Daya Beda Aitem Sub Skala Perceived Threat dan Desired Change.

\begin{tabular}{|c|c|c|c|c|c|c|c|}
\hline \multicolumn{4}{|c|}{ Sub skala perceived threat } & \multicolumn{4}{|c|}{ Sub skala desired change } \\
\hline Aspek & Aitem & Aiken (V) & $r_{i-t}$ & Aspek & Aitem & Aiken (V) & $\mathrm{ri}_{\mathrm{i}-\mathrm{t}}$ \\
\hline \multirow[t]{10}{*}{ Harm } & 1 & .73 & .28 & Importance & 1 & .70 & .35 \\
\hline & 2 & .56 & .43 & & 2 & .61 & $* *$ \\
\hline & 3 & .70 & $* *$ & & 3 & .73 & .41 \\
\hline & 4 & .71 & $* *$ & & 4 & .72 & $* *$ \\
\hline & 5 & .58 & $* *$ & & 5 & .55 & .42 \\
\hline & 6 & .61 & .40 & & 6 & .65 & .33 \\
\hline & 7 & .73 & .23 & & 7 & .77 & .37 \\
\hline & 8 & .55 & $* *$ & & 8 & .65 & $* *$ \\
\hline & 9 & .82 & .39 & & 9 & .67 & .30 \\
\hline & 10 & .55 & .32 & & 10 & .60 & .28 \\
\hline \multirow[t]{12}{*}{ Danger } & 1 & .76 & .31 & Upset & 1 & .61 & .28 \\
\hline & 2 & .73 & .35 & & 2 & .74 & $* *$ \\
\hline & 3 & .55 & .46 & & 3 & .59 & .37 \\
\hline & 4 & .61 & $* *$ & & 4 & .64 & $* *$ \\
\hline & 5 & $.47^{*}$ & $* *$ & & 5 & .61 & .48 \\
\hline & 6 & .52 & $* *$ & & 6 & .73 & .38 \\
\hline & 7 & .60 & .32 & & 7 & .61 & $* *$ \\
\hline & 8 & .63 & $* *$ & & 8 & .59 & $* *$ \\
\hline & 9 & .77 & $* *$ & & 9 & .73 & .29 \\
\hline & 10 & .73 & $* *$ & & 10 & .58 & .40 \\
\hline & 11 & .52 & .33 & & & & \\
\hline & 12 & .79 & .36 & & & & \\
\hline \multirow[t]{9}{*}{ Worry } & 1 & .80 & .26 & Motivation & 1 & .76 & .24 \\
\hline & 2 & .74 & .33 & & 2 & .63 & $* *$ \\
\hline & 3 & .73 & .22 & & 3 & .72 & .38 \\
\hline & 4 & .58 & $* *$ & & 4 & .64 & .23 \\
\hline & 5 & .56 & $* *$ & & 5 & .73 & .41 \\
\hline & 6 & .79 & .39 & & 6 & .58 & $* *$ \\
\hline & 7 & .76 & .43 & & 7 & .73 & .24 \\
\hline & 8 & .70 & $* *$ & & 8 & .61 & .44 \\
\hline & 9 & .82 & .28 & & 9 & .81 & .30 \\
\hline
\end{tabular}

Reliabilitas $(\alpha)=.76 ; \mathrm{k}=18$

Reliabilitas $(\alpha)=.78 ; \mathrm{k}=21$

Catatan: *aitem dengan nilai $\mathrm{v}<.50$; *aaitem yang memiliki nilai diskriminasi yang tidak memadai; ri-t = korelasi aitem total (daya diskriminasi); $\mathrm{k}=$ jumlah aitem yangmemiliki nilai $\mathrm{ri}_{\mathrm{t}-\mathrm{t}} \geq .22$. 
minimal skor hipotetik dengan skor empirik cukup jauh, di mana nilai minimal skor empirik lebih tinggi dibandingkan dengan skor hipotetik. Hal ini mengindikasikan bahwa responden memiliki atribut ukur yang tinggi dari pada yang diharapkan untuk masing-masing faktor maupun aspek.

Daya beda aitem dan koefisien reliabilitas sub skala perceive threat dan desired change

Delapan belas aitem memiliki daya beda yang baik pada sub skala perceived threat dengan koefisien reliabilitas alpha sebesar .76 sedangkan sub skala desired change terdapat 21 aitem dengan reliabilitas alpha sebesar .78.

Sebanyak $40 \%$ aitem yang gugur dari keseluruhan aitem yang diuji pada sub skala perceived threat sedangkan pada sub skala desired change terdapat $31 \%$ aitem yang gugur. Aitem yang gugur pada ke dua sub skala diakibatkan oleh aitem yang memiliki kata atau kalimat yang kurang jelas, konteks aitem yang tidak cocok dengan kondisi responden dan aitem yang memiliki kepatutan sosial yang tinggi. Lebih lengkap, nilai daya beda aitem ke dua sub skala dapat dilihat pada Tabel 4 .

\section{Confirmatory factor analysis (CFA)}

Untuk mencari model yang fit, 5 model telah dirancang. Hasilnya tampak pada data Tabel 5. Dari 5 model yang dibuat tidak satupun model yang fit. Model pertama dibuat menggunakan semua aitem yang mempunyai daya beda yang memenuhi syarat. Dari hasil yang didapat, terlihat bahwa baiknya daya beda aitem belum tentu menghasilkan model yang fit.

Model ke dua dibuat dengan menggunakan aitem yang memiliki faktor loading yang signifikan. Dari hasil yang didapatkan juga terlihat bahwa model menunjukkan nilai kriteria yang tidak fit.

Model ke tiga dibuat dengan menggunakan aitem yang memiliki nilai faktor loading $\geq .30$. Hasil dari model tersebut juga tidak fit. Hasil ini mengindikasikan bahwa aitem yang memiliki nilai faktor yang tinggi juga belum tentu membuat model menjadi fit.

Model ke empat dibuat dengan menggunakan 5 aitem dari masing-masing aspek. Pemilihan aitem dilakukan berdasarkan besarnya nilai faktornya. Hasilnya tetap menunjukkan model yang tidak fit. Namun bila dibandingkan dengan model yang sebelumnya, model ini mendekati fit.

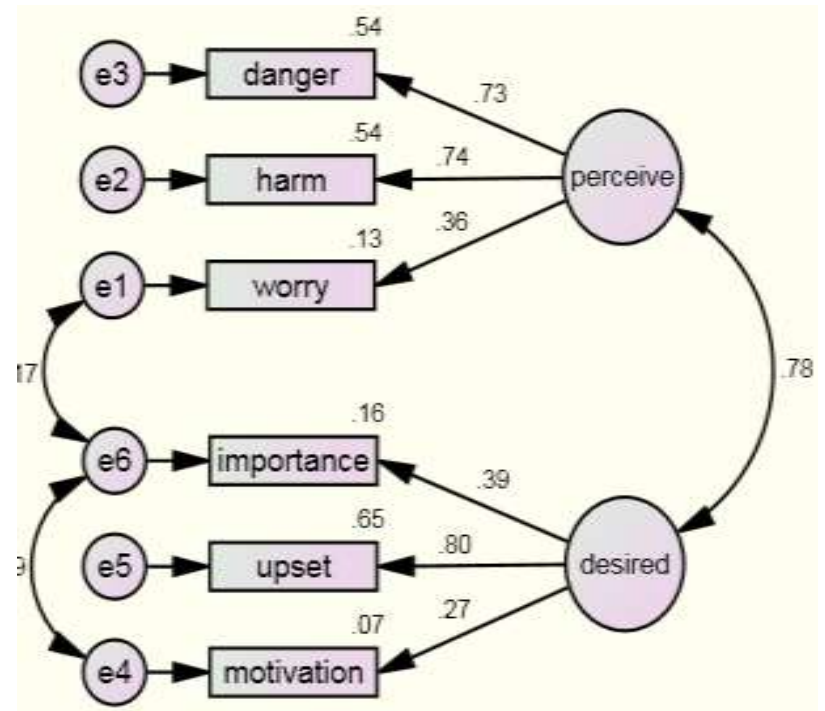

Gambar 1. Model CFA yang terdiri dari 5 aitem setiap aspek.

Model kelima dilakukan untuk melihat bila kedua sub skala dihilangkan akan memperoleh model yang fit atau tidak. Dengan kata lain faktor perceived threat dan desired change dihilangkan dan ke enam aspek langsung mengukur variabel peduli. Model ini juga menunjukkan hasil yang tidak fit.

Tidak adanya model yang fit dari semua model yang dirancang maka dilakukan proses modification indices pada model (Takeuchi, Miyaoka, Tomada, Suzuki, Lu, dan Kitamura, 2011). Dari ke lima model pada Tabel 5 hanya model ke empat menghasilkan model fit ketika dilakukan proses modification indices. Model yang dihasilkan dengan melakukan model tersebut seperti pada Gambar 1. 
Dari gambar 1 nilai CFI $=.96$; $\mathrm{TLI}=.92$, GFI $=.98$, dan RSMEA $=.75$. Dari nilai tersebut model ini dapat dikatakan fit. Model ini mengindikasikan terdapat korelasi antara worry, importance dan motivation. validitas isi baik. Setidaknya dengan satu aitem yang gugur telah cukup meyakinkan kita bahwa skala ini telah memiliki validitas isi yang baik.

Tabel 5. Model CFA yang Dirancang

\begin{tabular}{lccccc}
\hline \multicolumn{1}{c}{ Model } & TLI & CFI & GFI & RMSEA & Chi-square $(\mathrm{p})$ \\
\hline $\begin{array}{l}\text { Aitem dengan semua daya } \\
\text { beda yang diterima }\end{array}$ & -.16 & .04 & .64 & .49 & $2507.71(.001)$ \\
$\begin{array}{l}\text { Aitem dengan nilai } \\
\text { faktor loading signifikan }\end{array}$ & -.19 & .02 & .63 & .49 & 2416.43 \\
$\begin{array}{l}\text { Aitem dengan nilai } \\
\text { faktor loading } \geq .30\end{array}$ & & & & & $(.001)$ \\
$\begin{array}{l}\text { Lima aitem masing-masing } \\
\text { aspek }\end{array}$ &. .48 & .00 & .61 & .51 & 2579.14 \\
Satu dimensi & .75 & .87 & .94 & .14 & $(.001)$ \\
& .73 & .83 & .94 & .14 & 71.80 \\
& & & & & 87.165 \\
\end{tabular}

\section{Diskusi}

Penelitian ini merupakan kajian tentang pembuatan alat ukur atau skala psikologis. Kajian ini lebih fokus pada pembuatan dan evaluasi dari skala yang telah dibuat. Skala yang dibuat pada penelitian ini adalah skala kepedulian terhadap pengguanaan energi. Proses pembuatan skala diawali dengan memilih konsep yang cocok untuk mengambarkan kepedulian. Setelah itu aspek dan indikator-indikator perilaku diturunkan dari konsep yang digunakan. Selanjutnya, aspek dan indikator yang telah terkumpul didiskusikan dengan dua orang pakar dan diikuti dengan pembuatan aitem. Aitem yang telah selesai dibuat, dilakukan proses uji lapangan dengan memberikannya kepada responden penelitian. Hasil dari lapangan akan dievaluasi dengan melihat bagaimana hasil dari validitas isi dan validitas konstruk.

Validitas isi skala kepedulian terhadap energi menunjukkan hasil yang sudah baik. Hal ini dibuktikan dengan hanya satu aitem yang memiliki nilai Aiken di bawah .50. Tidak ada patokan khusus berapa jumlah aitem yang harus memiliki nilai $\mathrm{V}$ yang memadai untuk menyatakan suatu skala memiliki
Hasil pengisian skala oleh responden menunjukkan skor empirik lebih tinggi dibandingkan dengan skor hipotetik untuk semua aspek pada skala yang dibuat. Hal ini mengindikasikan banyaknya aitem yang berada pada setiap aspek memiliki kepatutan sosial yang tinggi. Ketika responen mengisi aitem tersebut cenderung akan memilih respon sangat setuju atau setuju pada aitem favorable dan sangat tidak setuju atau tidak setuju pada aitem unfavorable bukan karena situasi sebanarnya melainkan karena aitem tersebut lebih bersifat normatif, misalnya aitem "asap motor dapat menganggu kesehatan saya". Akibatnya, skor yang didapatkan akan cenderung lebih tinggi dari yang diharapkan. Indikasi lain dari tingginya skor empirik dibandingkan dengan skor hipotetik adalah kecenderungan responden untuk menampilkan sisi baik diri mereka. Responden cenderung akan menyetujui aitem-aitem yang berisi hal-hal baik seperti hemat penggunaan bbm, mematikan motor ketika lampu merah, mematikan kipas angin ketika keluar rumah dengan tujuan untuk menampak sisi baik mereka bukan situasi yang sebenarnya. 
Validitas konstruk pada penelitian ini menggunakan pendekatan confirmatori factor analysis (CFA). Hasil dari model CFA menunjukkan bahwa aspek worry berkorelasi dengan aspek importance dan aspek importance berkorelasi dengan aspek motivation. Dari hasil tersebut gambaran seseorang yang peduli dapat digambarkan. Ketika seseorang mementingkan suatu masalah yang terjadi ia cenderung akan mencemaskan masalah tersebut dan termotivasi untuk menyelesaikannya. Seseorang yang menganggap penting penipisan bahan bakar minyak (BBM) yang sedang terjadi ia akan merasa cemas akan kesulitan mendapatkan BBM dan termotivasi untuk menghemat pemakaian BBM.

Kajian tentang kepedulian masih belum banyak dilakukan dalam konteks keilmuan psikologi. Pada penelitian ini penjelasan tentang kepedulian digunakan konsep Amburgrey (2012) yang merupakan hasil penelitian tentang kepedulian terbaru. Konsep Amburgrey (2012) ini belum banyak diaplikasikan di dalam penelitian lainnya, sehingga bisa dikatakan konsep kepedulian yang ditawarkan oleh Amburgrey (2012) belum mempunyai bukti yang kuat untuk dapat digeneralisasikan. Namun, Hasil dari peneltian ini menunjukkan bahwa konsep kepedulian dari Amburgrey (2012) memberikan hasil yang baik. Banyaknya aitem yang gugur pada penelitian ini bukan gambaran dari buruknya konsep yang digunakan melainkan kesalahan pada proses pengembangan aitem itu sendiri.

Peneliti menyarankan pada penelitian selanjutnya untuk melakukan penelitian konstruksi konsep kepedulian di Indonesia. Karena konsep yang dikembangkan Amburgrey (2012) yang dillakukan di Amerika belum sepenuhnya cocok untuk diterapkan di kontek Indonesia karena banyak perbedaan budaya, politik, infrastruktur dari ke dua negara.

\section{Kesimpulan}

Dua sub skala kepedulian terhadap penggunaan energi yang telah dirancang memiliki validitas isi yang baik. Daya beda aitem menunjukkan banyaknya aitem yang memiliki daya beda yang rendah. Rendahnya daya beda aitem dikarenakan banyaknya aitem yang memiliki kata atau kalimat yang kurang jelas, konteks kalimat yang kurang cocok dengan responden dan memilki kepatutan sosial yang tinggi.

Struktur internal dari skala belum menunjukkan hasil yang optimal karena beberapa model yang dirancang dari skala tidak menunjukkan hasil yang fit. Model fit diperoleh ketika model telah melalui proses modification indices.

\section{Kepustakaan}

Amburgey, J. W. (2012). Toward a new conceptualization of environmental concern: Perception of threat and motivation for change as underlying psychological dimensions. Utah: University of Utah.

Azwar, S. (2012). Penyusunan skala psikologi. Yogyakarta: Pustaka pelajar.

BPS, (2010). Penduduk Indonesia menurut Provinsi 1971, 1980, 1990, 1995, 2000 dan 2010. Diunduh dari www.bps.go.id, diakses pada tanggal 15 November, 2013.

Cook, C. E., Cleland, J., Pietrobon, R., Garrow, A. P., \& Macfarlane, G. J. (2007). Calibration of an item pool for assessing the disability associated with foot pain: An application of item response theory to the Manchester Foot Pain and Disability Index. Physiotherapy, 93: 89-95.

Dunlap, R. E. (2008). The new environmental paradigm scale: From marginality to worldview use. The Journal of Environmental Education, 40(1).

Dunlap, R.E., \& Jones, R. E. (2002). Environmental concern: conceptual and measurement issues. Dalam R. E Dunlap \& W. Michelson, Handbook of environmental sociology. Wesport: Greenwood. 
Dunlap, R. E., Van Liere, K. D., Mertig, A. G. \& Jones, R. E. (2000). Measuring endorsement of the ecological paradigm: A revised NEP scale. Journal of Social Issues, 56, 425-442.

Furr, R. M., \& Bacharach, V. R. (2008). Psychometrics an introduction. Los angeles: Sage.

Hasla, A., Gamble, A., Juliusson, A., \& Garling, T. (2008). The relationship between awareness of consequences, environmental concern and value orientation. Journal of Environmental Psychology, 28: 1-9.

Hawcroft, L. C., \& Milfont, T. L. (2010). The use (and abuse) of the new environmental paradigm scale over the last 30 years: A meta-analysis. Journal of Environmental Psychology, 30: 143-158.

Huijts, N.M.A., DeGroot, J. I. M., Molin, E.J.E., \& VanWee, B. (2013). Intention to act toward a local hydrogen refueling facility: moral consideration versus self-interest. Transportation Research Part A, 48: 63-74.

Jacovcevic, A., \& Steg, L. (2013). Sustainable transportation in Argentina: Values, beliefs, norms and car use reduction. Transportation Research Part F, 20: 70-79.

Karpiak, C. P., \& Baril, G.l. (2008). Moral reasoning and concern for the environment. Journal of Environmental Psychology, 28: 203-208.

Kementrian Energi dan Sumber Daya Mineral. (2011). Efisiensi dan konservasi energi di Indonesia. Jakarta: Direktorat jenderal energi terbarukan dan konservasi energi kementrian energi dan sumber daya mineral Indonesia.

Kline, R. B. (2005). Principles and practice of structural equational modeling, $2^{\text {nd }}$ edition. London: The Guilford Press.

Osumanu, I. K. (2007). Environmental concern of poor households in low income cities: The case of the Tamala Metropolis, Ghana. Geo Jurnal: 68:343-355.

Shahbaz, M., Hye, Q. M. A., Tiwari, A. K., \& Leito, N.C. (2013). Economic Growth, energy consumtion, financial development, international trade and $\mathrm{CO}_{2}$ emmision in Indonesia. Reneweble and Sustainable Energy Reviews, 25: 109-121.

Singhirunnusorn, W., Luesopa, P., Pansee, J., \& Sahachaisaeree, N. (2012). Student's behavior toward energy conservation and models of transportation: A case study in Mahasarakham university. Social and Behavioral Science, 35: 764-771.

Singh, R., \& Setiawan, A. D. (2013). Biomass energy policies and strategies: Harvesting potential in India and Indonesia. Renewable an Sustainbility Energy Reviews, 22: 322-345.

Snelgar, R. S. (2006). Egoistic, altruistic and biospheric environmental concern: Measurement and structure. Journal of Environmental Psychology, 26: 87-99.

Steg, L., Dreijerink, L., \& Abrahamse, W. (2005). Factor influencing the acceptability of energy policies: A test of VBN theory. Journal of Environmental Psychology, 25: 415425.

Takeuchi, M., Miyaoka, H., Tomada, A., Suzuki, M., Lu, X., \& Kitamura, T. (2011). Validity and reliability of Japanese version of the temperament and character inventory: A study of university and college students. Comprehensive Psychiatry, 52: 109-117.

Urban, J., \& Scasny. (2012). Exploring domestic energy saving: The role of environmental concern and backround variables. Energy Policy, 47: 69-80.

Van Birgelen, M., Semeijn, J., \& Behren, P. (2011). Explaining pro environmental consumer behavior in travel. Journal of Air Transportation Management, 17: 125-128.

Wijaya K. (2010). Prospek bioetanol di Indonesia. Dalam Jusmina,. Wijaya, K., \& Budiman, A, Dari Yogyakarta untuk energi Indonesia: Pandangan dan hasil riset pakar Universitas Gadjah Mada di bidang energi. Yogyakarta: Pusat study energy UGM. 
Yen, N. S., Shakur, E. S. A., \& Wai, C. W. (2010). Zhang, Y., Wang, Z., \& Zhou, G. (2013b). Energy conservation opportunities in Malaysian Universities. Malaysian Journal of Real Estate.

Determinant of employee electricity saving: The role of social benefits, personal benefits and organizational electricity

Zhang, Y., Wang, Z., \& Zhou, G. (2013a). Antecedents of employee electricity saving climate. Journal of Cleaner Production, behavior in organization: An empirical S0959-6526(13)00697-5.

study based on norm activation model. Energy Policy, 62: 1120-1127. 